\title{
Reconsidering tutorials and student-lecturer power relationships in language subjects
}

\author{
Mustapha TAIBI \\ Departamento de Filología Moderna \\ Universidad de Alcalá, Madrid
}

Received: 10 October 2005 / Accepted version: 24 February 2006

ISSN: $1697-7467$

\begin{abstract}
The power relationship between teachers/lecturers and students may have negative effects on the process of learning because it can limit both 'physical' and verbal access to the teacher/lecturer and give rise to a relatively negative attitude towards him/ her. This is why reconsidering that power relationship and trying to reduce the power asymmetry is likely to improve both the relationship and the student's learning and performance. A way to contribute to bridging the distance between student and lecturer and also enhance personalized teaching and learning is tutorials. This article reports the results of an "experiment" that was carried out, with such objectives in mind, in the Teacher Training School of Guadalajara (University of Alcalá).

Key words: learning process, power, distance, tutorials.
\end{abstract}

RESUMEN: La relación de poder entre profesores y alumnos puede acarrear consecuencias negativas para el proceso de aprendizaje. Por eso si se reconsidera esta relación y se reduce la asimetría entre los dos participantes en el proceso educativo, es probable que mejoren la relación entre los dos y el rendimiento de los alumnos. Una forma de hacerlo es replantearse el concepto de "tutoría". Este artículo presenta los resultados de una experiencia en este sentido llevada a cabo en la Escuela de Magisterio de Guadalajara (Universidad de Alcalá).

Palabras clave: proceso de aprendizaje, poder, distancia, tutorías.

\section{INTRODUCTION}

The collocation "tutorials and power relationships" is perhaps striking. However, if we take into consideration the fact that tutorials are just part of the institutionalised relationships between lecturers and students, we can make sense of the combination. For the circle of relationships between the two participants in the educational process includes different contexts such as the classroom, the lecturer's office, administration, etc. and different kinds of subrelationships such as expert-lay person, information provider-information seeker, assessorassessed, etc. Therefore, (re)considering tutorials is part of (re)considering the student-lecturer power relationship (but not necessarily just that).

The aim of reconsidering this relationship is to create a non-traditional and friendly learning context in which the relationship tends towards cooperation and camaraderie rather 
than, or more than, distance and power asymmetry. For, if this is achieved, especially in language learning contexts, some of the key factors in the learning process will be positively affected, especially the learner's attitude, motivation and inhibition ("appropriate teacher behaviour and good teacher-student rapport" and "a pleasant and supportive classroom atmosphere" as conditions for motivation strategies, according to Thanasoulas, 2002).

This paper intends to tackle the issue of the lecturer-student power relationship and the use and objectives of tutorials in a specific context, namely university subjects focused on or related to active second language learning. The background to this discussion is the author's own experience as a lecturer in English Language at the Escuela de Magisterio (Teacher Training School) of Guadalajara (University of Alcalá), an experience starting from a nontraditional conception of lecturer-student relationship and a more practical (and, I hope, more effective) approach to tutorials. In addition to this experience and direct (participant) observation, this paper reports the findings of a five-question questionnaire intended to elicit the students' feedback on the tutorials of the academic year 2003-2004.

It should be noted that the reported experiment of the academic year 2003-2004 was not a research experiment. Rather, it was an innovative teaching and tutorial experience which was judged worth reporting once it was finished. That is to say, seeing that the students (would-be English teachers) generally had a low English language competence, that the class time was not sufficient to make a significant change, and that the general practice regarding tutorials was that both lecturers and students assumed they were intended only for occasional consultations, I decided to approach tutorials differently. Thus, the space and time allotted to them were reconsidered as a space and a time intended to support the students, enhance their learning process and create a less asymmetrical relationship between lecturer and student. Seeing the good results that this experience yielded, I judged it worth reporting. Therefore, it could be said that, in a sense, it was a kind of unintended action research.

\section{Power relationships in the Classroom}

According to Dahl (1957: 203) "A has power over B to the extent that he can get B to do something that B would not otherwise do". The key to power then, according to this author, is the ability to get (or make) and the fact of getting (or making) another person (or not necessarily a person) (to) do something (he or she would not otherwise do). In other words, Dahl defines power as causality and agency: A causes B to act and, therefore, acts him/herself. Dye (1990: 4), on the other hand, provides a definition that seems to be broader and more comprehensive:

Power is the capacity to affect the conduct of individuals through the real or threatened use of rewards and punishments. Power is exercised over individuals or groups by offering them some things they value or by threatening to deprive them of those things. These values are the power base, and they can include physical safety, health, and well-being; wealth and material possessions; jobs and means to a livelihood; knowledge and skills; social recognition, status, and prestige; love, affection, and acceptance by others; a satisfactory self-image and self-respect. To exercise power, then, control must be exercised over the things that are valued in society. 
In the educational context the relationship between teacher and student has been taken as a paradigmatic power relationship. "Whichever way we look at it", Thanasoulas (2002) states, "this relationship is riddled with power and status". This is because it involves getting the student to do something, as Dahl (1957) would say, especially when the teacher/lecturer asks students to do an assignment, a classroom task, etc.; it involves information/knowledge power (the teacher/lecturer being traditionally considered as the expert and source of knowledge) and the teacher/lecturer holds gatekeeping power (assessment/examination/failing or allowing access to the next grade or to a degree) and exercises interactional power (conversational control, prompting, interruption, etc.) as well as physical-access power (letting students in or out).

This kind of relationship is not very likely to encourage students to take the initiative, to participate freely in the educational process or to consider the lecturer as an approachable and cooperative partner. Rather, asymmetrical power relationships may inhibit the powerless party and, within the learning-teaching process, may affect the educational process negatively (Falchikov, 1986, referred to by Hirschy, 2002: 3). Therefore, a change is called for in order to create an environment where students can take the initiative and where a more democratic participation is encouraged (egalitarianism and tolerance in the classroom is one of six recommendations to improve undergraduate teaching and learning advanced by Eimers and Bayer (1996) referred to by Hirschy (2002: 11)). To do that, power relationships should be called into question and, as much as possible, smoothed out.

Reconsidering power relationships may take the form of loosening control over the classroom activities and the way they are carried out, allowing in more epistemological uncertainty (as opposed to monolithic truth), establishing a symmetrical and reciprocal relationship and using equal-to-equal terms of address, welcoming students' suggestions as far as contents, activities and methodology are concerned, etc. All this can lead students to identify themselves more with what goes on in the classroom, to adopt a more positive attitude towards their teacher/lecturer and subject matter and overcome the psychological barrier that usually holds many of them from asking questions, participating in classroom activities, etc.

In my experience, being aware that power relationships hamper the learning process has not led me to totally give up the privileged (powerful) position of the lecturer. Rather, starting from the premise that teacher behaviour is a powerful "motivational tool" (Dornyei, 2001: 120), I have been trying to mitigate and loosen the power relationship by adopting strategies and practices like the following:

- Asking the students at the beginning of (and during) the academic year about their expectations, preferences and priorities (with a view to boosting motivation and learning quality through "meaningful learning" and student-centred activities (Álvarez Rojo, 2000: 241)),

- Using the information obtained for continuous reference throughout the academic year,

- Allowing students to choose subjects of conversation, situations, etc. when the ongoing session or task is intended for them to practise speaking,

- Joining small groups of discussion as one of the members (although not completely forgetting about my role as teacher), 
- Admitting lack of knowledge when I do not know something offhand and admitting and apologizing for mistakes I may make,

- Establishing a camaraderie relationship (to some extent) with students, both inside and outside the classroom.

As it can be seen, the above strategies were intended, on the one hand, to reduce the distance and power gap between the two main participants in the educational process and, on the other, to create a student-centred "active methodology", which is highly recommendable if we want to enhance the learning process (Álvarez Rojo, 2000: 232). All this has led to a (generally speaking) friendly atmosphere in the classroom and a positive attitude among the students both towards the lecturer and the subject contents. What is more, even the students who were apparently shy at the beginning of the course, or lacked self-confidence because of their low linguistic competence in English, started to feel more at ease, participate more in classroom activities (especially speaking ones) and, therefore, improve their second language competence.

\section{TUtORIALS: WHAT FOR?}

To start with, it should be pointed out that the concept of 'tutorial' or 'tutoría' can be understood in different ways, depending on the educational system and the scope and objectives of each educational guidance service (See Lázaro Martínez, 1997: 75 for a summary of definitions). The Instituto Municipal de Educación Superior de Formación Docente (Buenos Aires, Argentina) defines tutorials as follows:

Son un elemento más de apoyo al aprendizaje del alumno. Éste tiene la posibilidad de que los profesores a cargo de la cursada se transformen en tutores que atienden, en momentos y espacios precisados previamente, las inquietudes y necesidades de cada alumno que se acerca, ayudando a salir de dificultades, a explorar nuevos campos, a propiciar el interés cuando éste decae, en definitiva, a facilitar y sostener el proceso de aprender. (www.capacyt.rffdc.edu.ar/servaca/1999/moduloblanco.html)

[They are an additional support element for the learning process. The student has the possibility to resort (at an arranged time and place) to the subject lecturer as a tutor who attends to the needs and worries of every individual, helping them to overcome difficulties, explore new fields, and recover motivation when it goes down. That is to say, to facilitate and support the learning process.] (My own translation)

In the English-speaking universities the tutorial system consists in the lecturer attending to small groups of students in order to explain and clarify contents already dealt with in class. In Spanish universities, according to Del Rincón Igea (2000), there are at least three types of tutorías: tutoría de enseñanza-aprendizaje (teaching-learning tutorials, which are, in principle, similar to the tutorial system in the English-speaking world), tutoría personalizada (dealing 
with the students' personal circumstances and problems and helping them to develop their personal autonomy, decision making and assertiveness) and tutoría de practicum (during the on-the-job traineeship period the tutor provides the student-trainee with professional advice and guidance linking the academic training and the on-the-job experience).

Lázaro Martínez (1997: 80-85) sums up the existing models in the Western universities in the following:

a. Bureaucratic-functional: limited to complying with the legal norms and requirements, attending to students at specific times, receiving assignments, and revising tasks and examinations.

b. Academic: strictly scientific/academic guidance, providing students/researchers with bibliographical information and guidance, research supervision, contact with research institutions, guided assignments, etc.

c. Teaching: tutorials for teaching-learning purposes, small-group classes, peer tutoring.

d. Personal advice: either informative-professional guidance and advice (interests, study itineraries, professional future) or advice on personal or private aspects (dealing with personal problems: affective, social, intellectual, academic, etc.)

However, in the Spanish context, especially in state universities, the first model is dominant (Lázaro Martínez, 1997: 80), although much attention has been shown to personal and professional advice in the last two decades.

Spanish universities have shown an increasing interest in tutorials and student advice in the last few years (Rodríguez Espinar, 2004: 32). Thus, presuming that the first academic year may be more problematic, many of them have designed and offered guidance courses and services for newcomers: "Reception programmes for newcomers" (the universities of Barcelona Autónoma, Jaime I, La Laguna, Madrid Pontificia, Murcia, Navarra and Valencia, among others), "Courses on study techniques" (Barcelona Autónoma, Jaime I, Balearic Islands, Zaragoza and the Basque Country, etc.), individual advice/tutorials (Deusto, Girona, La Laguna, Navarra Pública, the Basque Country, Salamanca and UNED), courses on career itineraries (Deusto, Granada, Navarra and Valencia have organized) and services of psychological, legal, etc. advice (Balearic Islands, La Laguna, Madrid Pontificia, the Basque Country and Zaragoza) (Echeverría, 1997: 123; Álvarez Rojo, 2000: 42).

For final-year undergraduate students Spanish universities have also organized courses, services and activities intended to provide some vocational guidance and a link between the university and the labour market. For example, some universities have offered programmes and courses on professional training and placement (Barcelona Autónoma, Barcelona Central, Granada, Madrid Carlos III, Madrid Pontificia, Murcia, Jaén, etc.). Some have organized round tables and presentations offering professional advice (Barcelona Central, Barcelona Pompeu Fabra, Jaime I, Navarra, Basque Country, Valencia, etc.). Some others have offered services including vocational advice and a sort of placement agency (Alcalá, Barcelona Central, Madrid Politécnica, Navarra, Oviedo, La Rioja, Salamanca, etc.) (Echeverría, 1997: 124).

However, although some universities have offered some guidance services to the students of the intermediate courses (e.g. information and advice on training, student exchange and grants, in universities like Alcalá, Barcelona Autónoma, Navarra, Granada, among others) (Echeverría, 1997: 123), there seems to be more interest in the entry and exit phases than in 
the problems the students might have during the university educational process (Valverde Macías et al., 2003: 272).

Álvarez Rojo (2000) reports the findings of a study on the factors contributing to academic success or failure, which was carried out among 1366 students and 125 lecturers of the University of Seville. Among the opinions and suggestions the subjects express it is worth highlighting the following:

- The need for a more personalized teaching-learning process (Álvarez Rojo, 2000: 246). Indeed, this is exactly what university tutorials, are supposed to do (Rodríguez Espinar, 2004: 28), especially if we understand them in the sense of tutoría de enseñanza-aprendizaje,

- A closer relationship between lecturer and student and a reconsideration of the academic authority/power (Álvarez Rojo, 2000: 246),

- Tutorials contributing to humanizing the process of teaching, the personal development of students, academic and professional advice and support for the learning process (Álvarez Rojo, 2000: 246, 248),

- Enhancing tutorials and improving their planning (Álvarez Rojo, 2000:296).

These aspects are likely to lead to an increase in student motivation and, at the same time, to the development of humanistic values such as freedom, creativity and critical attitude (Álvarez Rojo, 2000: 246).

In this paper as well as in the tutorial experience reported in it, the sense given to tutorials is in total agreement with the principles, objectives and suggestions summed up above by Álvarez Rojo (2000), and with the definition given above by the Instituto Municipal de Educación Superior de Formación Docente. That is to say, tutorials are conceived of as 'teaching-learning tutorials' in the sense of personalised attention or teaching which is intended to provide a parallel support for the student's learning and research processes and offer an individualized teaching approach (Del Rincón Igea, 2000: 35) in an educational context which is camaraderie-oriented more than power-laden.

\section{The TUtORIAL EXPERIMENT}

In Spanish universities the gap between the theoretical objectives of tutorials, as stated above, and their conception and use in practice, as far as I know, is quite wide. For there seems to be an agreement among students as well as lecturers that the time dedicated to tutorials is a time for the lecturer to be available in his or her office just in case a student shows up (Valverde Macías et al., 2003: 273), although some lecturers require that students arrange an appointment before going to their office. Similarly, there seems to be an agreement that tutorials are intended for the students to ask specific questions about subjects covered in class, that is to say when something is difficult to understand or more clarification is needed. Nonetheless, even for that specific and limited purpose it is a general observation that students do not make use of tutorials very often, which my own experience before the experiment and that of other colleagues in the University of Alcalá can only confirm.

Given this general context, on the one hand, and the particular context of the subject I 
taught (English as a Foreign Language) in the academic year 2003-2004 (a group of approximately 70 students, 40-45 of whom attended class regularly, low competence in the English language, only a couple of classes a week), and starting from a strong belief that "instructors can make intentional pedagogical choices that positively affect student learning" Hirschy (2002: 7) and that tutorials involve an ideology of commitment (Rodríguez Espinar, 2004: 148), I decided to introduce some change and extend my commitment to students' learning to the area of the lecturer's office.

Thus, to give tutorials a better use and to encourage students to seize the opportunity they offer them to enhance their learning process, improve their competence and acquire more self-confidence using a second language, I announced at the beginning of the 20032004 academic year that I would be available in my office on specific days at specific times, that those students interested in 'reserving' half, or a quarter of, an hour a week could do so, that the sessions could be for individual students, pairs or groups of three, that the students could use the time allotted to them for the purposes they wanted and according to their specific needs. I also made it clear that tutorials were optional and that, if needed, I would be available for more time than officially required.

The results of this initiative were the following:

- About 25 students (out of 40-45 who attended classes regularly) came to tutorials on a weekly basis and some others only occasionally,

- Tutorials were used to answer specific questions (both related to the subjects covered in class and related to the English language in general), to speak about free topics, to listen to songs, explain the lyrics and discuss them, to do interactive grammar exercises on the computer, to deliver presentations prepared by the students, to read news reports, to assess writing, etc.

- Some shy students improved significantly, as they felt more comfortable and selfconfident speaking in a small group or just to the lecturer-tutor. Similarly, students who had difficulty following the lecturer speaking in English became more used to it and gradually overcame that initial difficulty,

- Others took the initiative to look for materials on the Internet and prepare something for the tutorial sessions,

- Distance between lecturer and student was reduced. Indeed, as García Félix et al. (2003: 253) say, personalized tutorials encourage a more "human" relationship between lecturer and student and help students to stop perceiving their lecturer as inaccessible.

- Motivation improved considerably in the classroom.

\section{The STUdents' EVAluAtion OF THE EXPERIMENT}

In order to evaluate the above experiment with tutorials, I carried out a survey among the same group of students, once the academic year was over. The survey was carried out anonymously through a questionnaire (in the students' mother tongue, Spanish) consisting of the following five open-ended questions (although some questions could be considered yes/ no questions, the students were not provided with slots or cases to tick, but with a three-line dotted space to write on): 
1. How often did you attend tutorials of the Foreign Language (English) subject?

2. Did you find the contents of the tutorials satisfactory?

3. Do you think the lecturer's approach (as far as tutorials are concerned) was appropriate?

4. Did you have any expectations from tutorials that were not met?

5. Have you got any other comments or suggestions?

Forty-three students filled in the questionnaire, but some of them either returned the questionnaire in blank (because they had not attended tutorials at all) or failed to answer some of the questions. The findings were as the following two tables show (the first table is only about the frequency at which the surveyed students attended tutorials):

Table 1: Frequency of tutorial attendance

\begin{tabular}{|l|c|c|c|}
\hline & Once a week & Once a month & Never \\
\hline Question 1 & 25 & 11 & 7 \\
\hline
\end{tabular}

This table shows that, as mentioned above, 25 students (out of 40-45 who attended class regularly) came to tutorials once a week, which was a clear sign of the students' interest and motivation after they were offered a new approach to tutorials.

Table 2: Rest of findings (students' assessment of tutorials)

\begin{tabular}{|l|c|c|c|}
\hline & Yes & No & Do not know/ blanks \\
\hline Question 2 & 27 & 0 & 16 \\
\hline Question 3 & 26 & 1 & 16 \\
\hline Question 4 & 4 & 19 & 20 \\
\hline Question 5 & 7 & 26 & 10 \\
\hline
\end{tabular}

As the above table shows, the question number 2 (Did you find the contents of the tutorials satisfactory?) was answered affirmatively by 27 students $(62,79 \%)$. The question number 3 shows that 26 people $(60,46 \%)$ found "the lecturer's approach (as far as tutorials are concerned) was appropriate". The one student included in the "No" column did not actually say "no", but that he/she used to ask questions either in the classroom or after class, but not in the lecturer's office. The answers to the question number 4 reveal that 44,18\% (19 students out of 43) did not have unfulfilled expectations as far as the tutorials were concerned, while only $9,3 \%$ (4 students) did. Two of these latter suggested there should be more speaking activities, one of them suggested more grammar activities, while the other considered the relationship between lecturer and student should be closer. Finally, point number 5 in the questionnaire revealed that only a minority had other comments or suggestions $(7$, that is to say $16,27 \%$ ).

The seven comments or suggestions are the following:

a. "No con respecto a las tutorías pero sí opino que han sido pocas las clases (de inglés) en función de nuestra especialidad" [Not regarding tutorials, but as far as the English classes are concerned, I think the number is insufficient for our specialization]. 
b. "Solamente decir que me he sentido cómodo con esta asignatura y he aprendido y disfrutado con ella" [I only would like to say that I have felt comfortable with this subject, have learnt from it and enjoyed it].

c. "Las tutorías me sirvieron para ganar confianza en mi misma" [Tutorials have helped me gain in self-confidence].

d. "Está bien que haya una ayuda tutorial al menos a modo de guía en los diferentes aspectos de la asignatura" [It is a good thing to have tutorial assistance at least as a kind of guidance in relation to the different aspects of the subject].

e. "Debería haber todos los años tutorías" [There should be tutorials every year].

f. "Que me ha gustado tu forma de dar clase, y que nada, hasta la próxima" [That I liked the way you give classes and, well, see you next time].

g. "Es difícil sugerir algo porque no sabría como enfocar unas tutorías o preparar las clases de inglés de todo un cuatrimestre" [It is difficult to suggest something because I wouldn't know how to deal with tutorials or how to prepare English classes for a whole term].

It is clear from the above findings that the tutorial experiment was welcomed satisfactorily. Although a few students thought there should have been more attention to a specific skill or suggested more original topics or activities, the majority expressed positive feedback on the tutorial content and approach. Still, the relatively high number of students who either failed to answer a question or said they did not know (13 in the question number 4, for example, if we take out the 7 students who did not attend tutorials) could be interpreted as a polite negative answer or as a lack of the necessary insight to assess the quality of tutorials (as the quotation "g" above shows).

Finally, it is worth drawing attention to two significant details: the use of the "tu" address form by the student who wrote the quote "f" and the "suggestion" made by another in the quote "e" ("Debería haber todos los años tutorías" [There should be tutorials every year]). The first is a sign of the egalitarian culture I tried to create both in the classroom and in tutotial sessions, as the students normally tend to use the deference address term "usted". The second quote either shows some lack of knowledge about tutorials among some students (for tutorials are offered every year and every lecturer has subject-related tutorials) or refers to tutorials of the kind described in this paper, not tutorials in general, a reading which reinforces the general positive feedback reported above.

\section{Conclusion}

If attitude towards the subject matter and the teacher has traditionally been considered an important factor in the process of learning in general and in Second Language Learning in particular, power relationships between teacher and student should be taken into consideration, called into question and 'readjusted' in order to improve that attitude and, by so doing, enhance the learning possibilities. Similarly, if a non-power relationship in many cases requires a non-distance relationship and, knowing that when the teacher/lecturer deals with a whole (big) group of students, it becomes quite difficult to establish a closer relationship with them, reconsidering the function and use of tutorials could be a way to establish that kind of 
relationship, reduce the distance between the two main participants in the educational process and, what is more important, support the learning/teaching process by more personalised and closer attention.

\section{BiBLIOGRAPHY}

Álvarez Rojo, V. (dir.) (2000). Propuestas del Profesorado Bien Evaluado para Potenciar el Aprendizaje de los Estudiantes. Sevilla: Universidad de Sevilla.

Dahl, R.A. (1957). "The Concept of Power". Behavioural Science 2: 201-205.

Del Rincón Igea, B. (2000). Tutorías Personalizadas en la Universidad. Cuenca: Ediciones de la Universidad de Castilla-La Mancha.

Dornyei, Z. (2001). Teaching and Researching Motivation. England: Pearson Education Limited.

Dye, T. (1990). Power and Society: An Introduction to the Social Sciences. California: Brooks/ Cole Publishing Company.

Echeverría, B. (1997). "Los servicios de orientación universitarios" in Apodaca, P. and Lobato, C. (eds) Calidad en la Universidad: Orientación y evaluación. Barcelona: Laertes. 112-136.

García Félix, E.; Fernández March, A. and Serra Carbonell, B. (2003). "La formación integral de los alumnos a través de los profesores tutores: Experiencia de la Universidad Politécnica de Valencia" in Álvarez Pérez, P. and Jiménez Betancort, H. Tutoría Universitaria. La Laguna: Universidad de La Laguna. 245-255.

García Minguez, J. and García Guardia, G. (1983). Orientación y Tutorías. Granada: Universidad de Granada.

Hirschy, A.S. (2002). "The Sociology of the Classroom and Its Influence on Student Learning" in Peabody Journal of Education, 77(3), 85-100.

Lázaro Martínez, A. (1997). "La acción tutorial de la función docente universitaria" in Apodaca, P. and Lobato, C. (eds.) Calidad en la Universidad: Orientación y evaluación. Barcelona: Laertes. 71-101.

Rodríguez Espinar, S. (coord.) (2004). Manual de Tutoría Universitaria. Barcelona: Octaedro-ICE.

Valverde Macías, A.; García Jiménez, E. and Romero Rodríguez, S. (2003). "La función tutorial en la Universidad de Sevilla. La mentoría como respuesta: El proyecto SIMUS" in Álvarez Pérez, P. and Jiménez Betancort, H. Tutoría Universitaria. La Laguna: Universidad de La Laguna. 269-283.

Thanasoulas, D. (2002). "Motivation and Motivating in the Foreign Language Classroom" in The Internet TESL Journal, http://iteslj.org/Articles/Thanasoulas-Motivation.html. www.capacyt. rffdc.edu.ar/servaca/1999/modulo-blanco.html. 